\title{
The skeleton of mammoth Mammuthus trogontherii cf. chosaricus Dubrovo, 1966 from terminal Middle Pleistocene of the Lower Volga region (Russia)
}

\author{
Vadim V. Titov* \& Mikhail V. Golovachev \\ Vadim V. Titov, Institute of Arid Zones SSC RAS, Southern Scientific Centre RAS, Chekhov str., 41, 344006 Rostov- \\ on-Don, Russia [vvtitov@yandex.ru]; Mikhail V. Golovachev, Astrakhan State United Historical Architectural \\ Museum Reserve, Sovetskaya str., 15,414000 Astrakhan, Russia [golovachev3066@gmail.com]
}

\begin{abstract}
A skeleton of a male Mammuthus trogontherii cf. chosaricus is described from Chernyi Yar (Lower Volga Region), the type locality of this subspecies. The skeleton was discovered and excavated from clays of the Singil regional straton in 1996. The geological age of the enclosing sediments is estimated as the terminal Middle Pleistocene and correlated with MIS 7 - MIS 6. The individual age of the animal is estimated as 57-62 years. The calculated shoulder height of the skeleton is $312 \mathrm{~cm}$. Morphological differences from other forms of Mammuthus and Elephas (Palaeoloxodon) are discussed. The distinctions of dental and postcranial characters of $M$. trogontherii $\mathrm{cf}$. chosaricus, $M$. trogontherii trogontherii, and $M$. intermedius are reviewed. A diagnosis of the subspecies M. t. chosaricus is refined.

How to cite this article: Titov V.V., Golovachev M.V. 2017. The skeleton of mammoth Mammuthus trogontherii cf. chosaricus Dubrovo, 1966 from terminal Middle Pleistocene of the Lower Volga region (Russia) // Russian J. Theriol. Vol.16. No.1. P.15-29. doi: 10.15298/rusjtheriol.16.1.02
\end{abstract}

KEY WORDS. Mammuthus, skeleton, teeth, Eastern Europe, terminal Middle Pleistocene, Eastern Europe.

\section{Скелет мамонта Mammuthus trogontherii cf. chosaricus Dubrovo, 1966 конца среднего плейстоцена Нижнего Поволжья}

\author{
В.В. Титов, М.В. Головачёв
}

РЕЗЮМЕ. Описан скелет самца Mammuthus trogontherii cf. chosaricus из типового местонахождения подвида Чёрный Яр (Нижнее Поволжье). Находка была обнаружена и выкопана в 1996 г. из слоя сингильских глин. Геологический возраст вмещающих отложений оценивается как конец среднего плейстоцена и коррелируется с MIS 7 - MIS 6. Возраст особи оценивается в 57-62 года. Высота скелета в холке составляет 312 см. Рассмотрены морфологические сходства и отличия с другими представителями Mammuthus и Elephas (Palaeoloxodon). Показаны различия параметров зубов и костей посткраниального скелета $M$. trogontherii cf. chosaricus, M. trogontherii trogontherii и M. intermedius. Уточнён диагноз подвида M. t. chosaricus.

КЛЮЧЕВЫЕ СЛОВА: Mammuthus, скелет, зубы, терминальный средний плейстоцен, Восточная Европа.

\section{Introduction}

The Middle and Upper Pleistocene deposits are well exposed in coastal cliffs of the lower course of Volga River. They contain numerous shells of freshwater and brackish water molluscs and bones of small and large vertebrates. The "late Middle Pleistocene" Singil and Khazar mammalian faunal complexes (units) were established based on materials from the Lower Volga region (Gromov, 1935, 1948; Gromov et al., 1965). Recent studies considered these associations as different phases of the single late Middle Pleistocene mammalian complex. The fauna originating from Singil clays is roughly correlated with terminal Middle Pleistocene (MIS 7 - MIS 6). The mammalian assemblage from Upper Khazarian alluvium is correlated to early

* Corresponding author
Late Pleistocene (MIS 5) (Zastrozhnov et al., 2015, 2017 in press). Characteristic large mammals of this community are Canis lupus, Mammuthus trogontherii chosaricus, Stephanorhinus cf. kirchbergensis, Elasmotherium sibiricum, Equus latipes, Camelus knoblochi, Megaloceros giganteus, Cervus elaphus, Bison priscus, Bos primigenius, and Saiga tatarica. Chernyi Yar is one of the reference localities of the Khazar mammalian complex (Chernyi Yar village, Astrakhan Region, Russia; Fig. 1). The taxon Mammuthus trogontherii chosaricus Dubrovo, 1966 was defined based on the complete skull and mandible with M3/3 excavated in 1935 from the "Khazarian" deposits. A holotype of this elephant (collection of GIN; exposition no. PIN PMKP-4874/P-1520) is exhibited in the Paleontological Museum of Russian Academy of Sciences (Moscow) (Dubrovo, 1966). The exact stratigraphical position of this specimen is not known. But taking into 


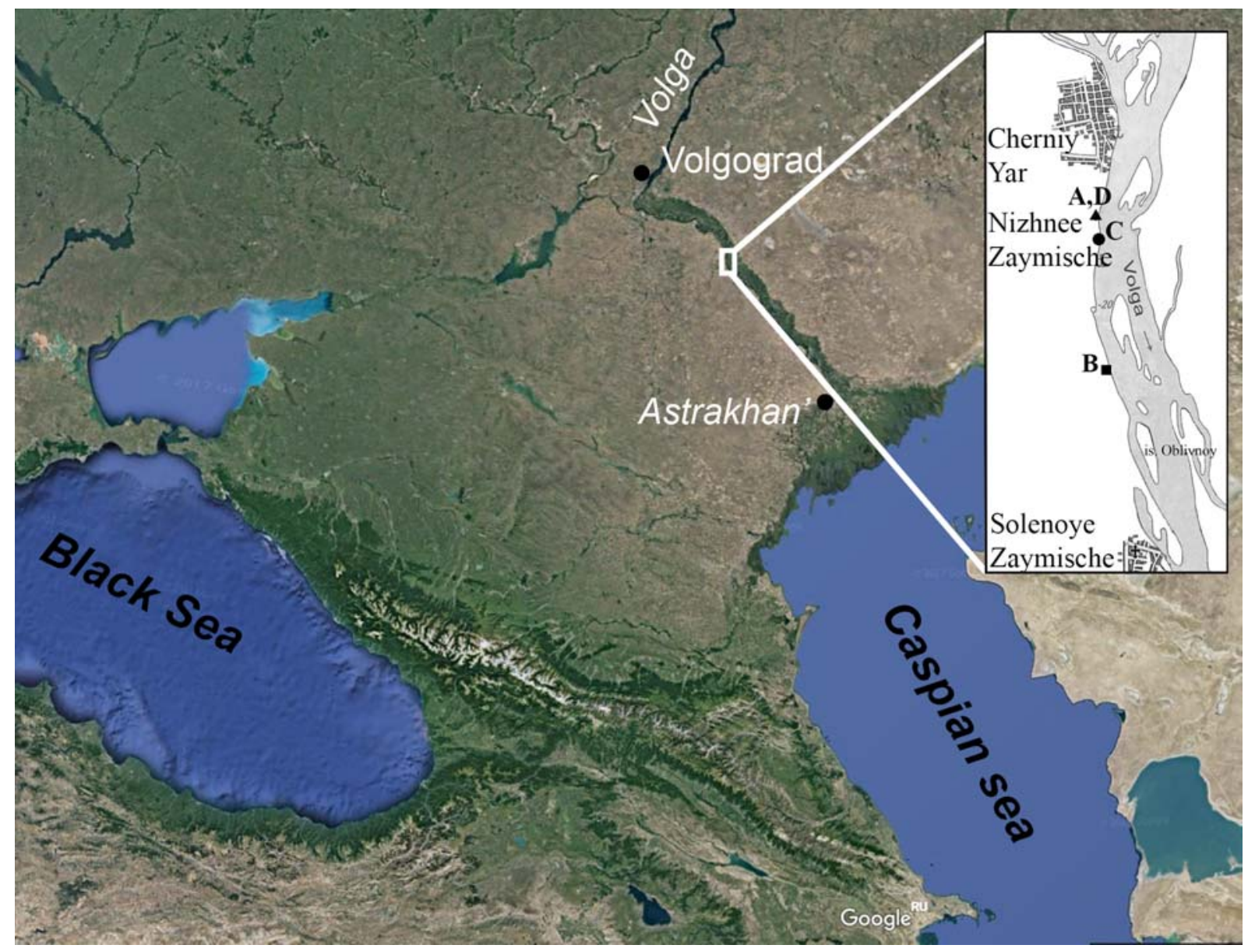

Fig. 1. Map of Lower Volga region with the location of Chernyi Yar site. A - incomplete skull of Mammuthus sp., 1968; B - the skeleton of Mammuthus trogontherii cf. chosaricus, 1996; C — incomplete skull of Mammuthus intermedius, 2013; D — the supposed locality of the skull of Mammuthus trogontherii chosaricus (holotype), 1935.

consideration the degree of fossilization, including the skull colour, and some indirect data we assume that it was buried at the base of the Upper Khazarian alluvium (Fig. 2).

This taxon was regarded as the index species of mammal associations of the second half of Middle Pleistocene in Southern and Eastern Europe. The systematic position of the Khazar (=Khozar) elephant is not entirely clear at the moment. Some researchers refer this taxon to the late form of $M$. trogontherii (Dubrovo, 1966). Others consider it as a separate species (Garutt, 1972; Gromow \& Garutt, 1975; Kotsakis et al., 1978; Alexeeva, 1990; Obada \& David, 2008). Some authors question the validity of this species and consider it as an intermediate form between trogontherine and woolly mammoths (Lister et al., 2005; Palombo \& Ferretti, 2005). This taxon is often confused with the recently reanimated species Mammuthus intermedius Jourdan, 1861 (Labe \& Guérin, 2005). Some paleontologists believe that the diagnosis of the Khazar elephant is mostly similar to that of the M. trogontherii (Foronova, 2001). Only several researchers support the indepen- dence of this taxon. This situation is primarily due to the fact that species are described in the literature based on isolated finds from different localities (Dubrovo, 1966; Garutt, 1972; Kotsakis et al., 1978; Dubrovo et al., 1979; Obada \& David, 2008). Currently there is no published description of the serial teeth material of the Khazar elephant form the type locality and its morphological variation is unknown.

The available representative collection of elephant teeth from the localities near the Chernyi Yar village is very heterogeneous. It was collected in different years and by different persons, commonly non-professionals. The situation is further complicated by the exposition of several fossiliferous beds in the coastal cliff near in this area. Teeth of Mammuthus originated both from the basal Singilian clays and from a relatively thick and lithologically variable overlying Upper Khasarian alluvium. In addition, there are isolated records from the stratigraphically higher Upper Pleistocene loess-like and sandy loams of the Atel Formation and Khvalynian marine and alluvial-marine deposits. Our earlier study of Pleistocene elephant teeth collection $(32 \mathrm{M} 3 / \mathrm{m} 3$ 


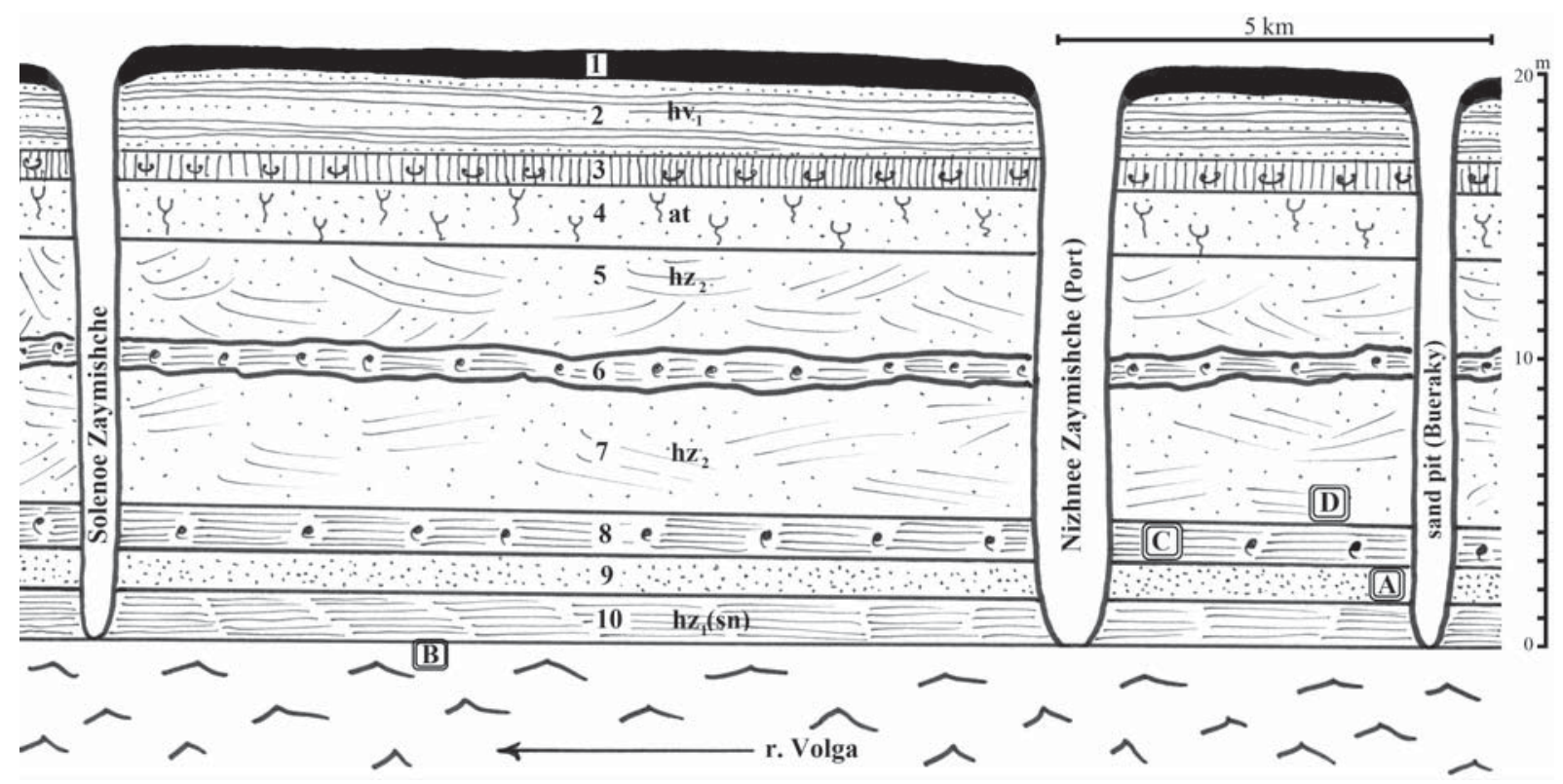

Fig. 2. Schematic composite cross-section of the Chernyi Yar locality with indicated provenance points of skulls and the described skeleton of Mammuthus (modified from Leont'ev \& Foteeva, 1965).

1 - modern soil; 2 - dark brown clays ("chocolate") Lower Khvalynian deposits; 3 - yellow-brown loess-like loams with shells of Dreissena, Didacna praetrigonoides, D. protracta; 4 - coarse sandy loams with plant remains (Atel beds); 5 cross-bedded light-brown sands with interbeds of brown sands and light white sands (Chernyi Yar beds); 6 — brown sandy clays; 7 - alternation of light yellow and light-brown sands and clays with inclusions of pebbles and separate interbeds of white sands (Upper Khazarian alluvial-marine deposits); 8 - basal part of Upper Khazarian alluvium with gravel at the base; 9 - level of modern beach; 10 - dark grey clays, horizontally layered, graiding at the top of the bed into sandy dirty-brown, sometimes gypsum clays with indistinct stratification (Singilian beds).

A — incomplete skull of Mammuthus sp., 1968; B — the skeleton of Mammuthus trogontherii cf. chosaricus, 1996; C — incomplete skull of Mammuthus intermedius, 2013; D - the supposed locality of the skull of Mammuthus trogontherii chosaricus (holotype), 1935.

specimens) from the Astrakhan Museum-Reserve revealed the presence of Mammuthus chosaricus, $M$. trogontherii, M. primigenius, Elephas (Paleaeoloxodon) cf. antiquus (Titov \& Golovachev, 2014). In the present contribution we refine these results.

In July 1996, during the low water period, the local people discovered bones of a large animal protruding from the right bank of the Volga River between the villages Solenoye Zaymische and Chernyi Yar (Fig.1: B). The team of the Astrakhan Museum-Reserve excavated a skeleton of fossil elephant. The bones occurred in the bed of Singilian compact blue clay (terminal Middle Pleistocene, late Middle - Late Saalian). The excavation exposed the skeleton lying on the right side with the legs facing the river side and the head oriented downstream and to the south (Fig. 3). The skeleton bones occurred in anatomical order (Golovachev, 2011). The legs were slightly bent under the body. Femurs were articulated with acetabula of the pelvis. The pelvis was separated into two halves. The tail was completely intact, and rolled down into a spiral ring. The bones rested on fossilised plant remains. The skull and tusks of the elephant were apparently destroyed by the river after the exposure of the skeleton. In addition, post- sedimentary processes destroyed the limbs below the knees. Only the left heel bone of the skeleton was unearthed nearby. The position of the skeleton indicates a short distance transportation and a subsequent burial by clayey sediments.

The restoration and reconstruction of the skeleton took four years. The new paleontological exhibition, with the mammoth skeleton as the central exhibit, opened in the Astrakhan Museum-Reserve in March of 2000. The missing bones (two thoracic vertebrae, 3 ribs, bones of the forearm and crus) were selected from the paleontological collection of the Museum. The skull, tusks, left humerus and bones of pes and manus were replaced by artificial copies.

\section{Material and methods}

Abbreviations. AMZ - Astrakhan united historical-architectural Museum-Reserve, Astrakhan, Russia

PIN - Paleontological institute RAS, Moscow, Russia

GIN - Geological institute RAS, Moscow, Russia

MGRI - Russian State Geological Prospecting University, Moscow, Russia 


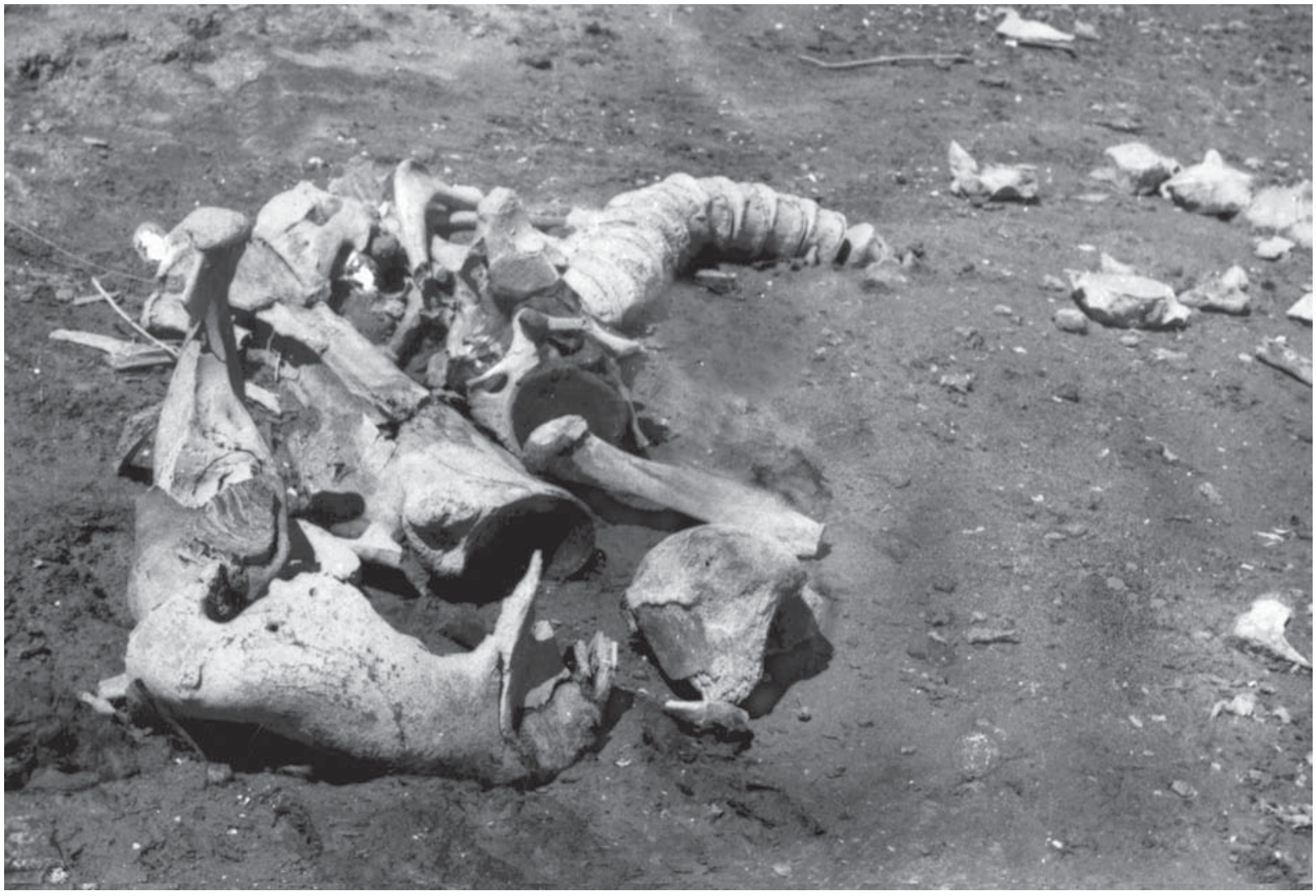

Fig. 3. The occurrence of the skeleton of Mammuthus trogontherii cf. chosaricus in the Singil beds of the of Chernyi Yar locality (July of 1996).

\section{LF — lamellar frequency \\ $\mathrm{L}$ - length \\ ET — enamel thickness}

The skeleton from Chernyi Yar (coll. AMZ, KP48423 ) is represented by the mandible with strongly worn third lower molars, right and left scapulae, complete set of the vertebrae (with the exception of the 7th and 8th thoracic bodies), the complete pelvis, full set of right side ribs $(n=20)$ and several left side ribs $(n=11)$, right humerus, incomplete left and right femurs with missing distal blocks, left calcaneus. The vertebral column of the elephant includes seven cervical, 20 thoracic, five lumbar, four sacral, and 19 caudal vertebrae (Fig. 4).

The degree of fossilization of bones is moderate. No signs of bone deformations are apparent. The bone surfaces are dark brown or black and grey-brown on the fractures. The teeth enamel is blue-grey.

For the description and comparison we used a series of upper and lower teeth, lower jaws of $M$. trogontherii chosaricus and $M$. intermedius from Chernyi Yar and its surroundings from collections of the Astrakhan $\mathrm{Mu}$ seum-Reserve (AMZ) and the Paleontological Institute RAS (PIN), Moscow (Tabs 1, 2, 3).

Measurements and characteristics of the tooth system follow the published standards (Dubrovo, 1960; Maglio, 1973; Garutt \& Foronova, 1976). Postcranial

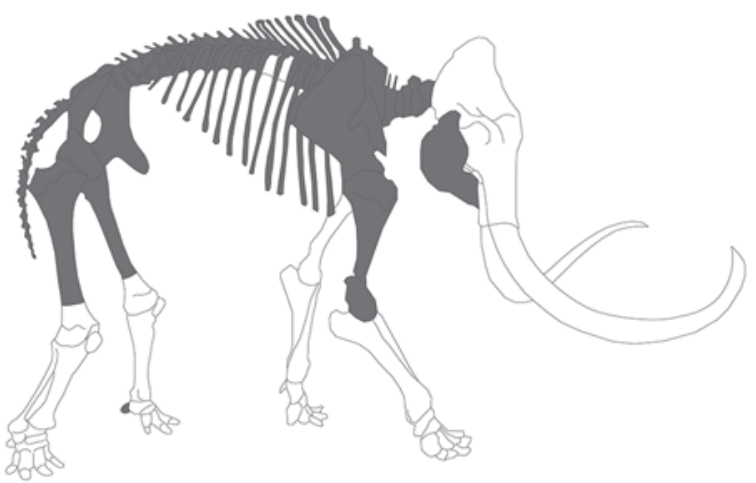

Fig. 4. Schematic representation of the Chernyi Yar skeleton of Mammuthus trogontherii cf. chosaricus, showing bone elements recovered. Terminal Middle Pleistocene, Lower Volga region, collection of the Astrakhan Museum-Reserve.

bones were described and measured according to von den Driesch (1976) with additions by Garutt (1954), Lister (1996), and Mol et al. (1999). Individual age was estimated by the averaged data of teeth generations (according to Garutt, 1977; Lister \& Stuart, 2010), and the regularity of epiphysis fusing of postcranial bones of the recent elephants Loxodonta africana and Elephas asiaticus (according to Lister, 1999). The shoul- 
der height estimation was made by Dubrovo (1975), Baygusheva et al. (2012), and Larramendi (2016).

\section{Results}

Family Elephantidae Gray, 1821

Tribe Mammuthini Osborn, 1921

Genus Mammuthus Burnett, 1830

Mammuthus trogontherii (Pohlig, 1885)

Mammuthus trogontherii cf. chosaricus

Dubrovo, 1966

Mammuthus trogontherii chosaricus: Dubrovo, 1966: 66,

Mammuthus chosaricus: Garutt, 1972: 35; Gromow \& Garutt, 1975: 453; Kotsakis et al., 1978: 412;

Mammuthus intermedius: Jourdan, 1861: 1010; Labe \& Guérin, 2005; Foronova, 2014: 71; Obada, 2014: 45;

Mammuthus trogontherii (late form): Lister et al., 2005: 60; Palombo \& Ferretti, 2005: 116;

Mammuthus primigenius (early form): Lister et al., 2005: 60; Palombo \& Ferretti, 2005: 116.

Emended diagnosis. Upper molars $\mathrm{M} 3 / 3$ have length of 225-(278.4)-335 mm, width of 89-108 mm (M3) and 74-98 (m3), number of plates on M3 - 2122 (including talons (=platelet)), m3 - 20-22 (including talonids (=platelet)), and M2 is 14-15. Lamellar frequency in M3 is 5.5-(6.4)-7.2, and 5.0-(6.3)-7.0 for $\mathrm{m} 3$. Lamellar frequency in strongly worn M3/3 is 5.0 5.5. Enamel thickness in M3/3, 2-(2.2)-2.5 mm. Enam- el plication from medium to strong. Median sinus on occlusal surfaces of weakly and medium worn plates is missing. The incipient wear figures on occlusal surface of trinomial plates are intermediate or antiquoid.

Remark. The emended diagnosis is mainly follows that of Dubrovo (1966). We, however, exclude specimens from Novogeorgievsk (M. trogontherii; Zakrevs$\mathrm{ka}, 1936)$ and from Troitsk of the Moscow Region ( $M$. intermedius, coll. MGRI No. 392) from the teeth sample originally used by Dubrovo (1966) for the diagnosis of the subspecies.

Description. The mandible (coll. AMZ, No KP$48423 / 1$ ) is relatively short, it has a high ascending branch (Tab. 1). The lower jaw angle is well expressed. The mental process is short, it is directed forward and down (Fig. 5a, b). The horizontal branches are short and low. The index of the height of the horizontal branch (the ratio of width to height at the level of the middle of m3) is 1.19. The symphysis is wide and high. Its height to length index is 0.94. A single foramen mentale, which is preserved only on the left half of the jaw, is located at the level of middle part of the symphysis. Teeth are close to each other. The distance between the inner surfaces of the $\mathrm{m} 3$ is $73 \mathrm{~mm}$. The divergence angle of the horizontal branches of the mandible is about $50^{\circ}$.

The lower teeth of the described skeleton are significantly worn (5-6 wear stage). The number of enamel

Table 1. Measurements of the lower jaws of Mammuthus from Chernyi Yar locality (late Middle Pleistocene), collection of Astrakhan Museum-Reserve, and Paleontological institute RAS.

\begin{tabular}{|c|c|c|c|}
\hline & \multicolumn{2}{|c|}{ Mammuthus t. chosaricus } & \multirow{2}{*}{$\begin{array}{c}\begin{array}{c}\text { Mammuthus } \\
\text { intermedius }\end{array} \\
\text { AMZ no. KP-45947 }\end{array}$} \\
\hline $\begin{array}{l}\text { Lower jaw } \\
\text { Measurements (mm) }\end{array}$ & $\begin{array}{c}\text { AMZ no. KP- } \\
\text { 48423/1, } \\
\text { skeleton }\end{array}$ & $\begin{array}{c}\text { PIN P-1520 } \\
\text { holotype }\end{array}$ & \\
\hline $\begin{array}{l}\text { Maximal length of mandible from the rostrum } \\
\text { to an articular process }\end{array}$ & $515.0 ; 540,0$ & - & 535.0 \\
\hline $\begin{array}{l}\text { Length from the anterior border of the alveolus } \\
\text { to posterior border of the ascending branch }\end{array}$ & 405.0 & 432.0 & 405.0 \\
\hline Maximal height of mandible & 440.0 & 550.0 & - \\
\hline $\begin{array}{l}\text { Length from the rostrum to the anterior border } \\
\text { of the alveolus }\end{array}$ & 177.0 & - & 154.0 \\
\hline $\begin{array}{l}\text { Anterior-posterior length of the ascending } \\
\text { branch }\end{array}$ & 273.0 & 294.0 & 248.5 \\
\hline $\begin{array}{l}\text { Maximum width between the outermost points } \\
\text { of the horizontal rami }\end{array}$ & 610.0 & 540.0 & $(505)$ \\
\hline $\begin{array}{l}\text { Maximum width between the outermost points } \\
\text { of the articular processes }\end{array}$ & 473.0 & 520.0 & - \\
\hline Length of symphysis & 106.0 & - & 86.0 \\
\hline Height of symphysis & 100.0 & - & 78.0 \\
\hline Height of the horizontal ramus at $\mathrm{m} 3$ & 138.0 & - & 137.0 \\
\hline Maximal width of the horizontal ramus & 164.0 & - & 134.5 \\
\hline Index of the height $(3: 2)^{*} 100$ & 108.0 & 128.0 & - \\
\hline Index of the ascending branch $(5: 2) * 100$ & 67.4 & 68.0 & 61.4 \\
\hline Index of mandible width $(6: 2) * 100$ & 150.6 & 125.0 & 124.7 \\
\hline Index of articular width $(7: 2) * 100$ & 107.5 & 120.0 & - \\
\hline
\end{tabular}




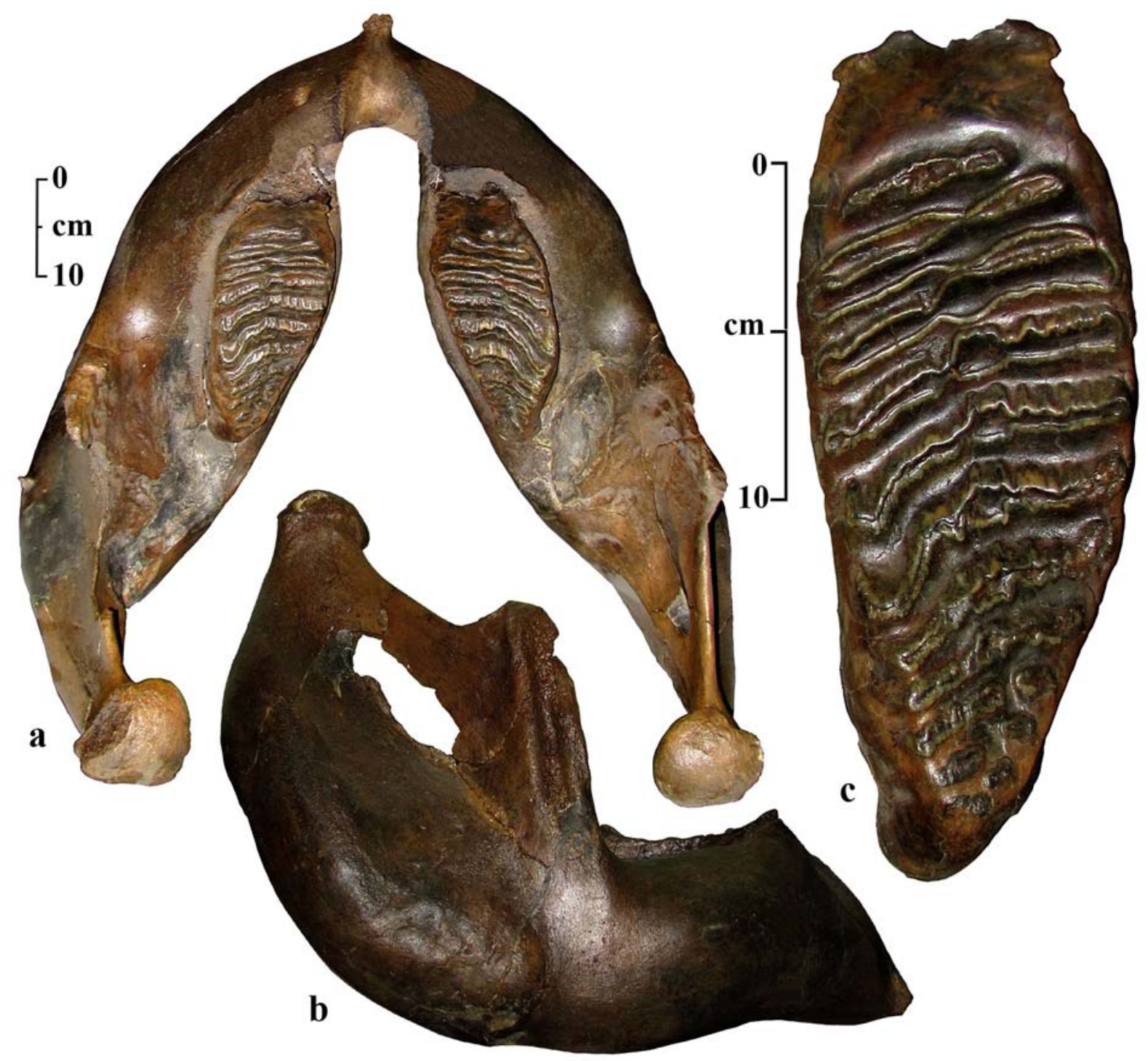

Fig. 5. Lower jaw of Mammuthus trogontherii cf. chosaricus from Chernyi Yar locality (Lower Volga Region, terminal Middle Pleistocene), collection of Astrakhan Museum-Reserve (AMZ no. KP-48423/1): a — upper view, b - lateral view, $\mathrm{c}$ - occlusal surface of left lower tooth $\mathrm{m} 3$.

plates composing the crown is more than 11 (Fig. 5c). The teeth show a moderate lamellar frequency $(5.0$ 5.25 ) and relatively thick plates (Tab. 2). The enamel thickness is $2.0-2.1 \mathrm{~mm}$. The enamel has a medium degree of folding but it is likely that it was more plicated in the medium worn teeth. The plates are skew outwards at about $21^{\circ}$ to the long axis of the tooth. The middle semicircular segment occurs on the strongly worn plates.

Crista atlantis on the upper arch of the first cervical vertebra (coll. AMZ No. KP-48423/2) is well-developed. The tuber and rugosity of muscle attachment developed on the first cervical vertebra. Usually these well-expressed features are characteristic for skeletons of males (Garutt, 1992; Averianov, 1996). The transverse processes are well developed (the ratio of atlas height to its width at the level of transverse processes is 51.23 ). The atlas width is 365 , its height is 187 , width of the articular surface for occipital condyles is 230 $\mathrm{mm}$, height of articular surface (right) is $110 \mathrm{~mm}$. The ratio of height to width of the articular surface for the occipital condyles is 0.48 .

The scapula (coll. AMZ No. KP-48423/84) is wide; it has a broad and slightly pronounced neck. The acromion is massive and located vertically relative to the plane of the scapula. The hill of the scapula ridge is large, it runs from the middle of the ridge and directed caudo-ventrally (Tab. 4).

The humerus (coll. AMZ No. KP-48423/86) is relatively slender, it has a pronounced relief. The head of the humerus is broad, slightly flattened. 


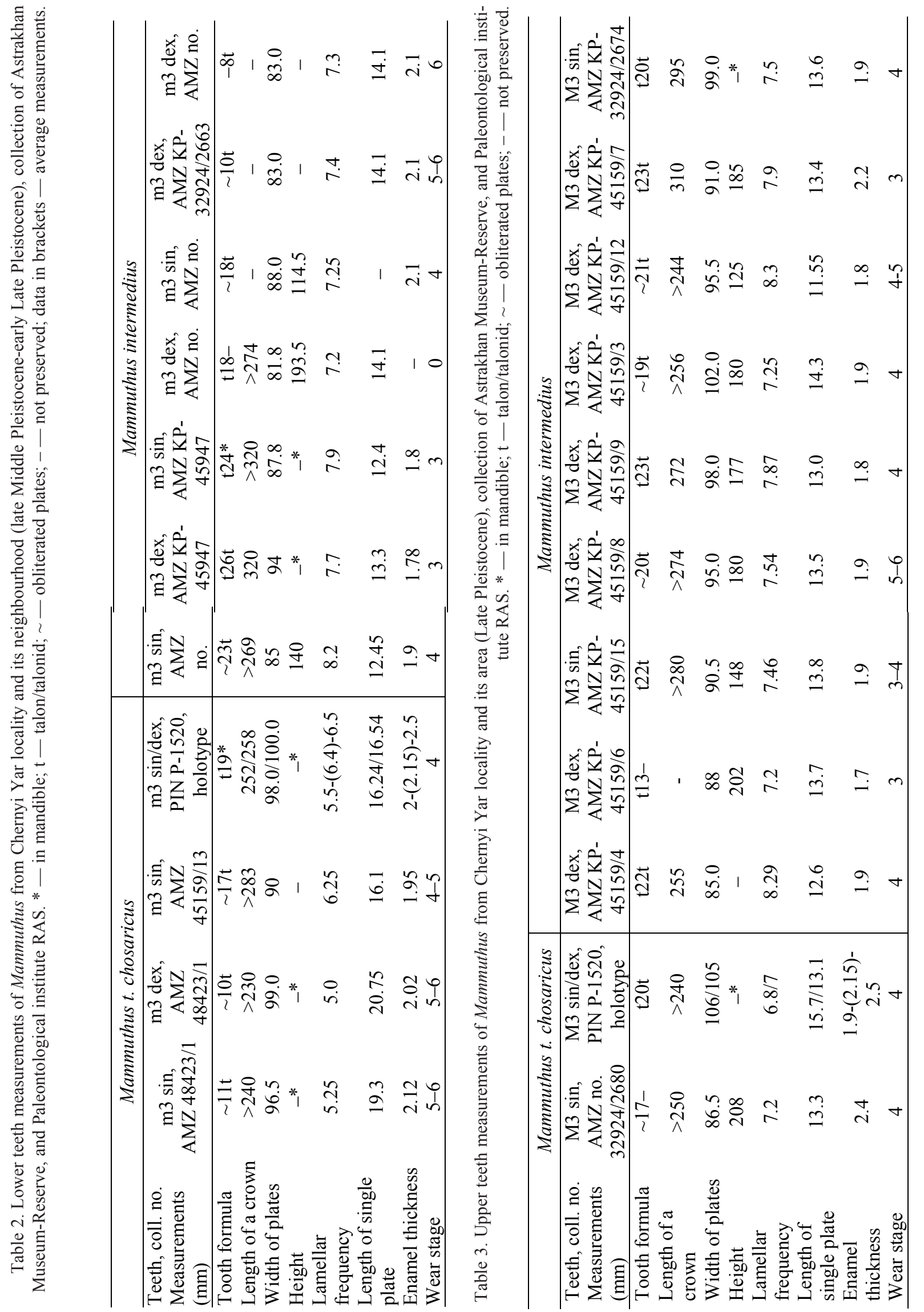


Table 4. Measurements of forelimb bones of Mammuthus trogontherii chosaricus from late Middle Pleistocene deposits of Chernyi Yar locality (Sea Lower Volga Region), collection of Astrakhan Museum-Reserve.

\begin{tabular}{lcc}
\hline \multicolumn{1}{c}{ Measurements, mm } & dex & sin \\
\hline $\begin{array}{l}\text { Scapula AMZ KP }-48423 / 86, / 85 \\
\text { Maximal length }\end{array}$ & - \\
Distance from a crown of the front corner to the middle of & 860.0 & - \\
articular socket & 695.0 & - \\
Distance from a back corner to the middle of articular & 540.0 & 272.0 \\
socket & 275.0 & 236.0 \\
Width of a head together with a tuber, maximal & 238.0 & 204.0 \\
Width of a neck of scapula & 201.0 & - \\
Length of articular socket & 125.0 & - \\
Width of articular socket & 747.0 & \\
Length of scapula crest & & \\
& \\
Maximal length & 1015.0 & \\
Length from the top of the humeral head to lateral edge of & 947.0 & \\
distal trochlea & 245.0 & \\
Maximal transversal diameter of a head & 265.0 \\
Width of proximal end & 306.0 \\
Transversal diameter of proximal end & 292.0 & \\
Maximal thickness of distal end (at the level of epiphyseal & 228.0 & \\
suture) & 212.0 & \\
Width of distal trochlea & 168.0 \\
Maximal thickness of medial trochlea & 134.0 \\
Maximal thickness of lateral trochlea & 329.0 \\
Height of a trochlea & 110.0 & \\
Height of lateral epicondyle & 137.0 & \\
Transversal diameter of diaphysis minimal &
\end{tabular}

The femur (coll. AMZ No. KP-48423/88, 48423/ 89 ) is relatively slender, with a poorly developed greater trochanter with the upper edge located at the level of the head base.

The pelvic aperture is sub-circular. According to the indices of the pelvis proposed by Lister (1996), the skeleton belongs to a male. The ratio of the main pelvic canal width and the minimum width of the ilium above the acetabulum is 1.97 (dex) and 2.13 (sin), which is less than 2.6-2.7 (female index) and is typical for males. The second index, the ratio of the length from the lowest point on the scar of the sacrum to the closest point on the midline of the lower edge of the pelvic canal to the minimum width of the ilium is 1.92 (dex) and 2.08 (sin), which is less than 2.4. It also indicates that the pelvis belongs to a male. Two halves of the pelvis (coll. AMZ No. KP-48423/87) are connected at the symphysis pubica by ossified cartilage (Golovachev \& Titov, 2015).

The specimen shows a rather late fusion of bones of the axial skeleton, which is typical for elephant males. Based on the degree of epiphyses fusion, the age of the described skeleton is defined around 45-50 years by analogy with the African elephant (Lister, 1999). The epiphyses of the vertebrae are fused only in the cervical and at the beginning of thoracic part of the spine. The caudal epiphyses of the vertebrae are unfused in the posterior part of the thorax, as well as in the lumbar and caudal vertebrae. On the ventral part of the pelvic bones cartilages have a pronounced semi-overgrown epiphysis suture and the open epiphyseal suture at a dorsal part. The epiphysis on the proximal end of the scapula is not fused. On the humerus the incompletely fused epiphysis sutures occur at the proximal joint. This suture is not visible on the distal part of the bone. The epiphysis sutures are also present in the proximal part of the femur. The fusion degree of the ribs heads is uneven. At the first six and three posterior pairs of ribs the heads are completely fused or there are fully closed epiphyseal sutures. On other ribs the epiphysis sutures of the heads are open. The unfused epiphysis occurs in the tenth rib.

Molars (m3) of the described skeleton, referred to 5-6 degree of wear, there are 10-11 plates left from 20-22 ones supposed for an unworn teeth. This stage pertains to XXVIII-XXIX groups of the African elephants by Laws (1966), and corresponds to 55 to $57 \pm 4$ years (based on Jachmann, 1988) or to the revised 5762 years (based on Lee et al., 2012). This age, in 
general, is also consistent with the calculated age based on the methodology of Stansfield (2015). In our case the distance of $10 \mathrm{~cm}$ from the "age reference point" to the "age reference line" falls on the edge of the last plate of $\mathrm{m} 3$.

At the twelfth right asternal rib (costae spuriae) there are traces of lifetime fracture. It was damaged at about half of the rib body length with the formation of a false joint.

Comparison. The significant degree of the teeth wear and the absence of the skull complicate the taxonomic placement of the skeleton. But the comparison of mandibular teeth with the available collection of elephant teeth from Chernyi Yar enable a secure attribution of the studied specimen to a subspecies.

The teeth characters (enamel thickness, length of one plate, lamellar frequency) of the described find AMZ No. KP 48423/1 are within the variability of M3/ 3 of the Cromerian mammoths from Süssenborn (Germany) and Tiraspol (Pridnestrovian Moldavian Republic), but differ in shorter crowns. Taking into account the large size variation of teeth from the type and reference localities of trogontherine mammoth, we assume a presence of several forms of elephants in these collections. Both sites belong to thick sedimentary sequences with multiple bone-bearing horizons. The syntype of $M$. trogontherii (coll. Senckenberg Research Institute and Natural History Museum, Weimar, Germany, No. 3153/2057, lower tooth m3, medium worn, fourth stage of wear), which was associated by H.F. Osborn (1942) and Dubrovo (Dubrovo, 1975; Kahlke, 1990) with the lectotype of this species, has the lamellar frequency of 6.3. This is a higher value than in the strongly worn teeth of the described skeleton (5-6 wear stage, $\mathrm{LF}=5.0$ and 5.25). The described teeth have a wider crown in comparison with the syntype but is within the variability of M3/3 from Süssenborn and Tiraspol. The width/length ratio of $\mathrm{m} 3$ in the specimen AMZ No. KP 48423/1 is 38-39 compared to 25-30 in the type series of $M$. trogontherii. The teeth enamel from Chernyi Yar jaws is more plicated and, on the average, thinner than in teeth of typical M. trogontherii.

The teeth of the described skeleton are similar to those of the holotype of $M$. trogontherii chosaricus (PIN P-1520), it differs in a lesser lamellar frequency, larger plate length and slightly smaller thickness of enamel. But taking into account a significant wear stage of teeth of AMZ No. KP 48423/1, it is assumable that in less worn teeth these values will largely coincide with those of the holotype. The values of enamel thickness published by Dubrovo (1966) can be considered exaggerated because the measurements were taken from the restored skull conserved with an adhesive. Our study supported that the enamel thickness is indeed somewhat exaggerated due to the surface glue layer on the teeth. This was noted by Foronova (2014, Fig. 4) with corrected data shown in her diagrams. According to this correction, the enamel thickness of the teeth AMZ No. KP 48423/1 coincides with that of the holotype of $M$. trogontherii chosaricus (Tabs 2, 3). It is noteworthy, that the increased folding of the enamel is typical even for strongly worn teeth of the described specimen. This feature is also characteristic for the Khazar elephant (Dubrovo, 1966).

The elephant from the Chernyi Yar locality differs from the late Middle Pleistocene - early Late Pleistocene $M$. intermedius (Jourdan, 1861) in a lower number of plates, lower lamellar frequency and longer plates (Tab. 2). In comparison with teeth of $M$. intermedius in the collection of AMZ from localities of the Lower Volga region, the teeth of the described specimen also shows a more folded enamel. These differences of dental characters occur in the teeth of all wear stages, including strongly worn specimens (Figs 6, 7).

The comparison with the dental characteristics of M. primigenius, including $M$. p. primigenius and $M$. $p$. fraasi, shows the notable differences, which are a greater enamel thickness and a smaller lamellar frequency in the specimen from Chernyi Yar (Fig. 8).

From teeth of forest elephants Elephas (Palaeoloxodon) antiquus Falconer et Cautley, 1847 the teeth of AMZ No. KP 48423/1 differ by smaller length of the plates, the reduced thickness of enamel. The lamellar frequency on the teeth of the specimen studied is within the variability of this parameter at forest elephants (Palombo \& Ferretti, 2005; Baygusheva \& Titov, 2008). But taking into consideration the strong degree of wear of the teeth from Chernyi Yar, we assume that it differs from $E$. (P.) antiquus both in lamellar frequency and in the number of plates. On the other hand, both forms have a noticeable enamel plication.

Dimensions. The shoulder height of the mounted skeleton from Singil deposits of Chernyi Yar is $3.0 \mathrm{~m}$. The height of the skeleton was calculated on the basis of the lengths of the humerus and the scapula, which have preserved completely. On the base of calculated correlations of limb bones length and skeleton height of some M. trogontherii (Pohlig, 1885) (from Odessa, West Runton, Steinheim, Edersleben) and southern elephants (from Nogaisk and Georgievsk), as well as of the large mammoth $M$. p. fraasi Dietrich, 1912 (Steinheim, Germany), the following data were obtained: the length of the scapula on the average amounts to $27.7 \%$ of the skeleton shoulder height, and the length of humerus, 32.4\% (Baygusheva et al., 2012). These data are similar with the values given by Dubrovo (1975) for woolly mammoths. Using these correlations we estimate the shoulder height of the studied individual as $312 \mathrm{~cm}$. It was a medium-sized mammoth. The estimated body height is $329 \mathrm{~cm}$ (shoulder hight*1.055, after Larramendi, 2016). According to the skeletal height and bone dimensions, the mass of the animal was approximately 6.2-6.5 tons (Christiansen, 2004; Larramendi, 2016).

In the bone length and shoulder height, the described mammoth is comparable to the so-called "early" mammoths from the late Middle and early Late Pleistocene of Germany, southern Russia, and Ukraine 

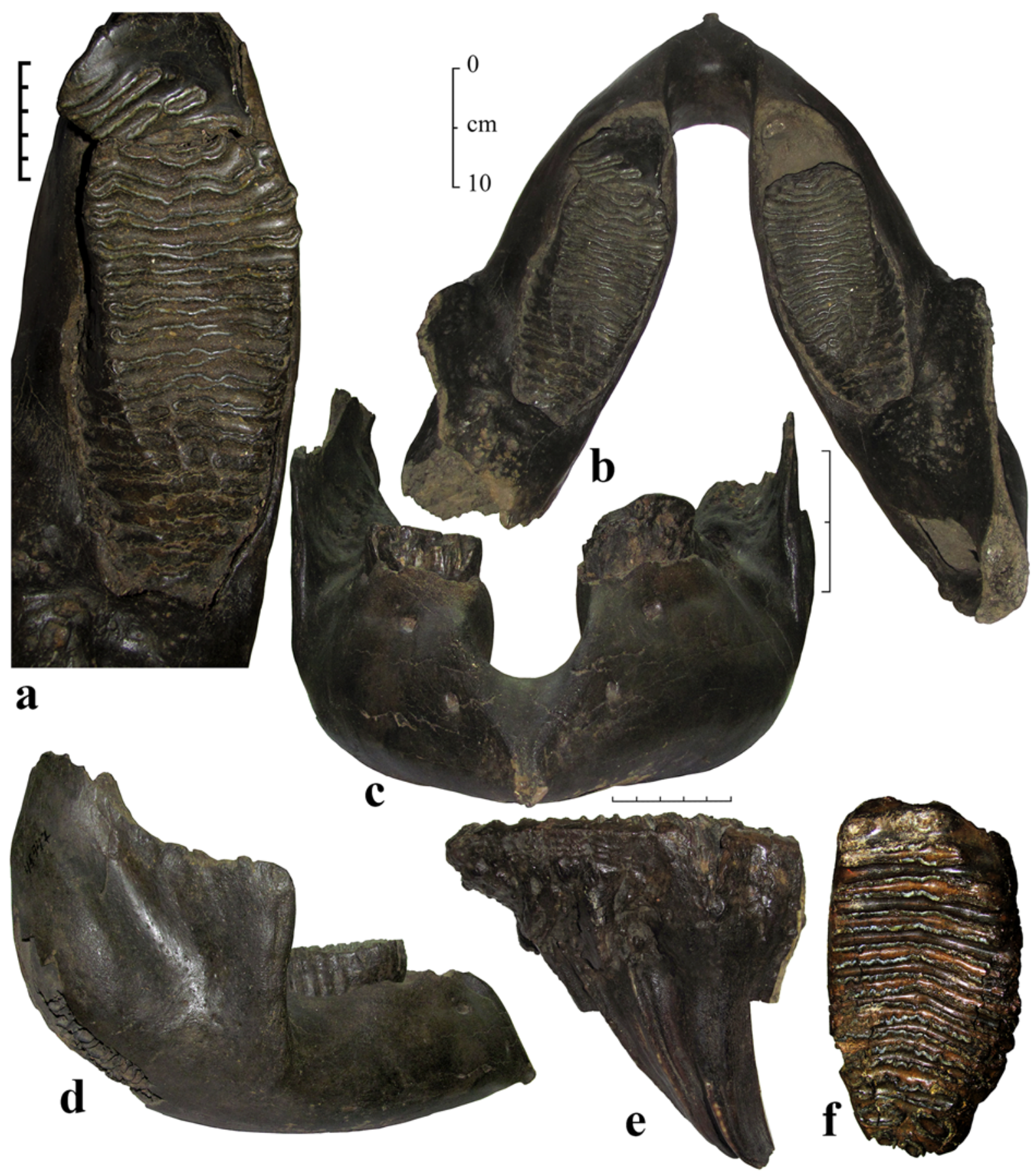

Fig. 6. Mammuthus intermedius from Chernyi Yar / Nizhnee Zaimische locality (Lower Volga Region, terminal Middle Pleistocene), collection of the Astrakhan Museum-Reserve, a-d - lower jaw (AMZ no. KP-45947): a - occlusal surface of left lower tooth $\mathrm{m} 3$ of 3 wear stage and fragment of $\mathrm{m} 2, \mathrm{~b}$ - upper view, $\mathrm{c}$ - anterior view, $\mathrm{d}$ - lateral view; right lower tooth m3 of 5-6 wear stage (no. AMZ 32924/2663): e — lingual view, f - occlusal surface.

(Baygusheva, 1980; Lister \& Stuart, 2010). The mammoth from the Lower Volga region has more massive limb bones, particularly the humerus, in comparison with similar by the height $M$. primigenius from Europe and Siberia of the late Late Pleistocene (Middle Valdai Megainterstadial, Weichselian, Denekamp Interstadi- al). In particular, the largest mammoth from Siegsdorf (Germany) is attributed to the latter group. The exceptions are M. primigenius from the Lena River (Yakutia; radiocarbon age $35800 \pm 1200$ years) and Rottweil (Germany, exact age unknown) which have humeral bones with similar massiveness (Fig. 9). 

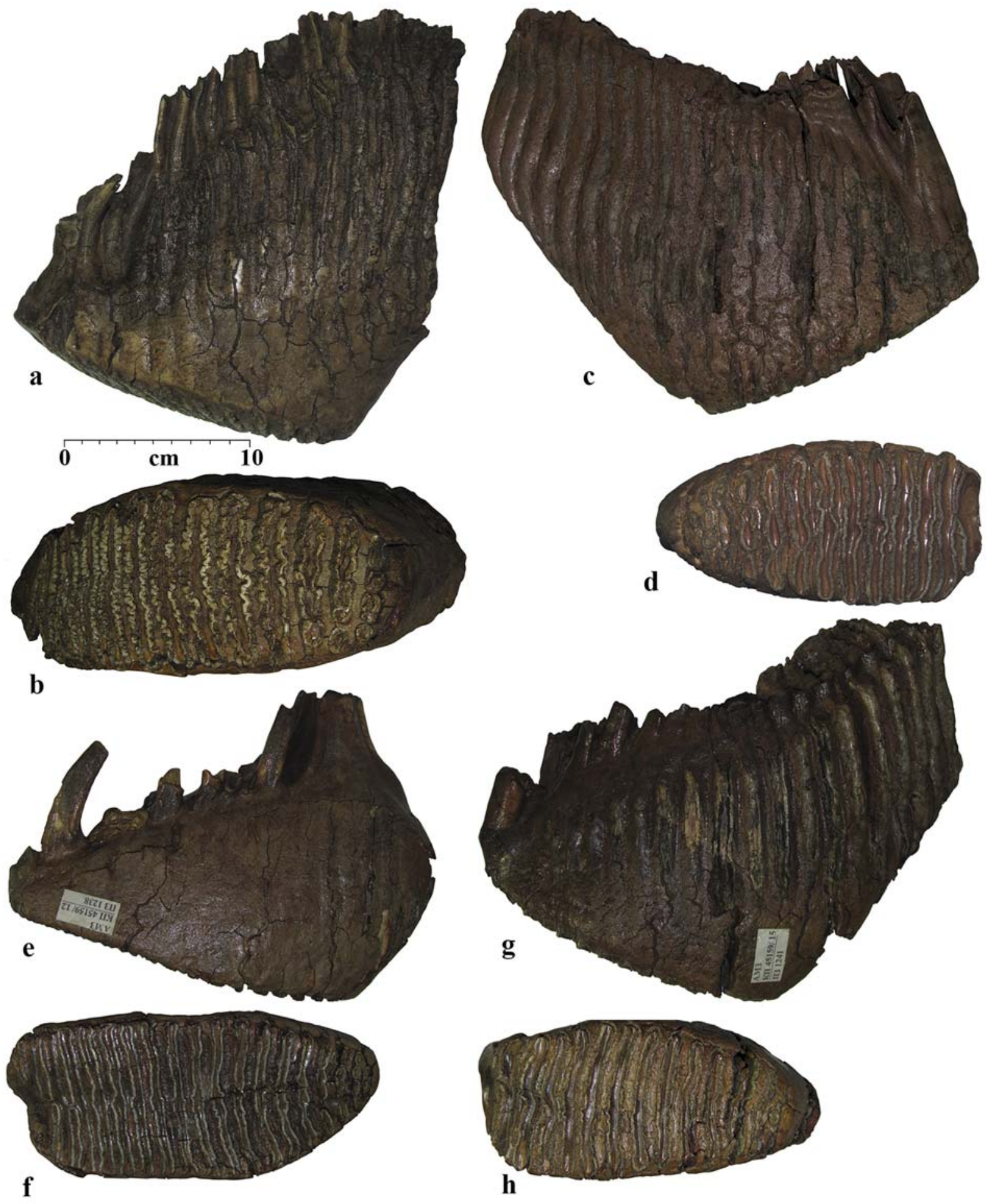

Fig. 7. Upper teeth M3 of mammoth Mammuthus from Chernyi Yar locality and its neighbouring (Lower Volga Region, terminal Middle Pleistocene - early Late Pleistocene), collection of the Astrakhan Museum-Reserve. M. t. chosaricus: left M3 AMZ No. 32924/2680: a — labial view, b — occlusal surface; M. intermedius: right M3 AMZ No. 45159/7: c — labial view, d - occlusal surface, right AMZ No. 45159/12: e — lingual view, f — occlusal surface, left M3 AMZ No. 45159/15: g labial view, $\mathrm{h}$ - occlusal surface. 


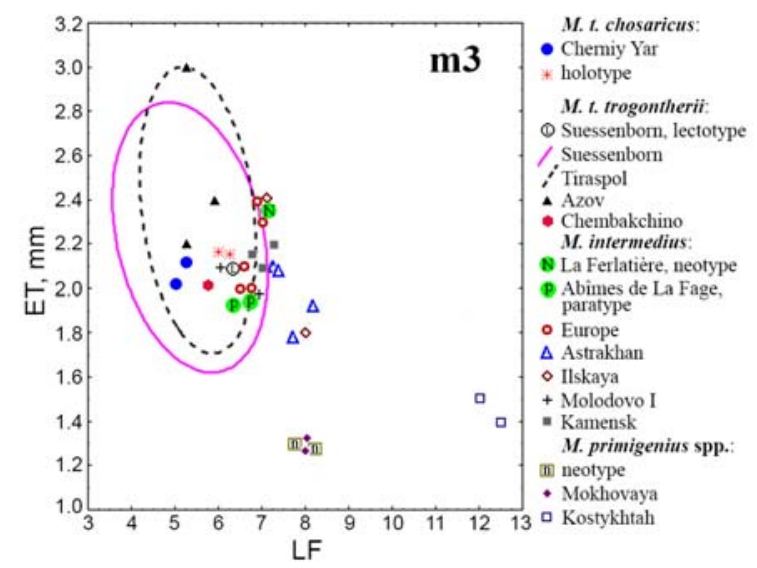

Fig. 8. The ratio of enamel thickness and lamellar frequency of some Middle-Late Pleistocene representatives of genus Mammuthus from Eurasia.

According to the size the skeleton of a male from Chernyi Yar is significantly smaller than trogontherine mammoths, meridionaloid and Paleaeoloxodon elephants (Lister, Stuart, 2010, Supplementary 2; Baygusheva et al., 2012). The humerus of the described elephant differs from the larger late Middle Pleistocene $M$. p. fraasi in a considerably higher massiveness.

The elephant from Chernyi Yar is larger than mammoths M. primigenius primigenius (Blumenbach, 1799) that occurred after the LGM (Late Valdai, Late Weichselian) from Russia (Krasnoyarsk, Taimyr, Sevsk) and France (Aa) (Averianov, 1994; Ziegler, 2001; Mashchenko, 2004; Kirillova et al., 2012).

\section{Discussion}

The validity of the Khazar elephant is still unclear. The comparison of dental characteristics shows a sig-

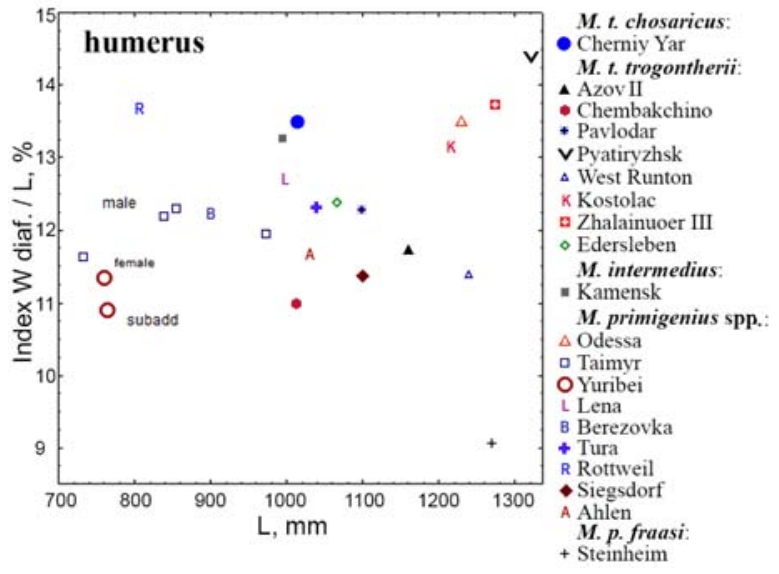

Fig. 9. The ratio of humerus maximal length to the index of humerus slenderness (diaphysis width: maximal length*100) of some Middle-Late Pleistocene representatives of the genus Mammuthus from Eurasia. The question mark (?) doubtful position.

nificant similarity of trogontherine and Khazar mammoth teeth (Fig. 8; Foronova, 2014). The situation is further complicated by the fact that the lectotype of $M$. trogontherii does not correspond to the mean values of the Süssenborn sample. Some features (enamel thickness, lamellar frequency) are similar the holotype of Khazar elephant. The comparison of their hypsodonty indexes is impossible, because the teeth of the holotype of $M$. trogontherii chosaricus are hidden in the jaws. We believe that the discovery of the mammoth skeleton from Chernyi Yar is a possible argument in favour of the independence of $M$. trogontherii chosaricus. Though showing similar dental features, the record from Lower Volga region differ noticeably from $M$. trogontherii trogontherii in smaller postcranial measurements and length of the teeth crowns, as well as in a significant

Table 5. Measurements of hind limbs bones of Mammuthus trogontherii cf. chosaricus from late Middle Pleistocene deposits of Chernyi Yar locality (Sea Lower Volga Region), collection of Astrakhan Museum-Reserve.

\begin{tabular}{lcc}
\hline \multicolumn{1}{c}{ Measurements, mm } & dex & sin \\
\hline \multicolumn{1}{c}{ Femur AMZ KP - 48423/88, /89 } & 162.0 & 161.0 \\
Transversal diameter of a head maximal & 144.0 & 144.0 \\
Width of a neck, minimal & - & 252.0 \\
Width of distal end (at the level of epiphyseal suture) & 142.0 & 150 \\
Width of diaphysis in the middle, minimal & 72.0 & 69.0 \\
Transversal diameter of a diaphysis, minimal & - & 208.0 \\
Os calcaneus AMZ KP -48423/90 & & 162.0 \\
Maximal length anterio-posterior & & 139.3 \\
Maximal width of proximal epiphysis & & 777 \\
Maximal DT proximal articulation facets & & 127.0 \\
Length anterio-posterior of proximal articulation facet & & 87.0 \\
Length anterio-posterior proximal epiphysis & & 69.0 \\
Length anterio-posterior tuber calcanei & & 142.0 \\
Minimal width of tuber calcanei & & 195.0 \\
Maximal height articulation facets & & \\
Maximal height of calcaneus (in life position) & & \\
\hline
\end{tabular}


Table 6. Measurements of pelvis bones of male of Mammuthus trogontherii cf. chosaricus from late Middle Pleistocene deposits of Chernyi Yar locality (Sea Lower Volga Region), collection of Astrakhan Museum-Reserve.

\begin{tabular}{lcc}
\hline \multicolumn{1}{c}{ Measurements, mm } & dex & sin \\
\hline \multicolumn{1}{c}{ Pelvis AMZ KP $-48423 / 87$} & \\
Maximal horizontal width of pelvic girdle & 1330 \\
Length of pubic symphysis & 430 & 99 \\
Thickness of the upper part of share bone & 420 & 370 \\
Maximal horizontal width of pelvic aperture & 380 & 390 \\
Height of pelvic aperture from sacrum to share bones & 390 & $(850)$ \\
Distance between ischial tuberosities & 860 & 164 \\
Diagonal height of pelvic aperture from pubic symphysis to lowest point & 174 \\
on the sacral attachment & 167 & 196 \\
Length of ilium, maximal & 187 & 105 \\
Longitudinal diameter of acetabulum & 110 & $(515)$ \\
Transverse diameter of acetabulum & 525 & 200 \\
Length of an oval aperture & 200 & \\
Width of an oval aperture & & \\
Width of ilium wing from tuber coxae to nearest point of pelvic aperture & & \\
Minimal width of ilium shaft above acetabulum & & \\
\hline
\end{tabular}

folding of the enamel. The lack of strong pathologies and signs of malnutrition and impaired growth indicates that we deal with a healthy adult individual. Thus, the set of characters makes it possible to separate these two taxa. The available differences in morphology and chronology provide evidence that the Khazar elephant was a deminished descendant of the typical Cromerian trogontherine mammoth and a may be assigned to a separate subspecies.

The sample of mammoth teeth from the Lower Volga region contains other finds with a dental morphology similar to M. trogontherii chosaricus. In particular, the upper M3, AMZ No. 32924/2680 (Fig. 7a, b) and lower m3, AMZ 45159/13 are identical with those of the holotype of Khazar elephant (Tabs 2,3) in all characters including the strong plication of the enamel.

Relatively numerous upper and lower teeth of $M$. intermedius in the collection of AMZ allow to estimate a range of morphological variability in Lower Volga representatives of this taxon (Figs 6,7). This in turn gave us an opportunity to separate $M$. $t$. chosaricus from $M$. intermedius.

We assume the coexistence of two elephant species in Eastern Europe during the late Middle - early Late Pleistocene. One of them, M. trogontherii chosaricus, has a slightly thicker and more plicated enamel. This implies that this form, probably less widespread, fed upon softer forage of leaves and twigs. The second elephant, $M$. intermedius, was probably more adapted to the diet of herbaceous forage. Another Middle - Late Pleistocene elephant, Elephas (Palaeoloxodon) antiquus had a relatively thick and plicated enamel too. The forest elephant probably periodically dispersed from Southern and Central Europe and spread in Eastern Europe along the river valleys during warm periods with the expansion of forest vegetation (Alexeeva, 1990).

\section{Conclusions}

The described mammoth skeleton AMZ No. KP48423 from the Chernyi Yar locality is ascribed to the adult male of Mammuthus trogontherii cf. chosaricus with the individual age of 57-62 years. Meaningful pathologies on the bones were not recorded. The Khazar elephant was significantly smaller than early Middle Pleistocene trogontherine elephant, which is considered to be the largest elephant of the mammoth lineage. Available features of the dental system indicate a significant proximity of this form to typical $M$. trogontherii, as was pointed out by Dubrovo (1966). But the combination of the characteristics of the teeth and postcranial skeleton of elephants from Singil clays and the Khazar alluvium of the Lower Volga Region (the collection of AMZ), allows to distinguish the mammoth form from the typical early Middle Pleistocene trogontherine elephants. Dental characters and postcranial skeleton features indicate $M$. trogontherii chosaricus as a smaller Late Saalian - Early Weichselian descendant of Cromerian $M$. trogontherii trogontherii. Our results show the differences of Khasar elephants from the late Middle - early Late Pleistocene $M$. intermedius. M. trogontherii cf. chosaricus from the Lower Volga Region differs from $M$. primigenius in dental characters and the proportions of the limb bones.

One of the specific features of the Khasar mammoth is a relatively thick and plicated teeth. In this feature it differs from the coexistent $M$. intermedius and later $M$. primigenius, but is similar to the forest elephant $E$. $(P$.) antiquus. This feature probably indicates the separation of ecological niches between $M$. trogontherii chosaricus and coeval $M$. intermedius. The Khasar elephant probably inhabited wooded areas of steppe landscapes, which were present in the south of Eastern Europe during late Middle - early Late Pleistocene. 
ACKNOWLEDGEMENTS. The authors thank the inhabitant of Chernyi Yar village Nikolay Kasyanov, who discovered the skeleton and promptly reported the unique find. We are grateful to the staff of the Astrakhan Museum-Reserve, and to archaeologists E.M. Pigarev, A.B. Novichkov, and $\uparrow$ A.Yu. Sumin for their help during the excavations and the creation of the original construction during the mounting of the skeleton, as well as the Astrakhan sculptor S.Y. Skisov for the manufacture of plaster cast of the skull. We are grateful to the former Governor of Astrakhan Region $\uparrow$ A.P. Gujvin for the financing of the excavation, restoration and reconstruction of the skeleton and constant moral support. Special thanks are to E.N. Mashchenko and A.N. Kharitonov (both Paleontological institute RAS) for valuable advices and recommendations on conservation and restoration of bones. We also thank two reviewers for the improvement of the manuscript. The study was supported by the Russian Science Foundation, project no. 16-17-10170.

\section{References}

Alexeeva L.I. 1990. [Upper Pleistocene theriofauna of Eastern Europe (large mammals)]. Moscow: Nauka. 109 p. [in Russian]

Averianov A.O. 1994. [Kutomanov's Mammoth] // Trudy Zoologicheskogo instituta AN SSSR. Vol.256. P.111135 [in Russian].

Averianov A.O. 1996. Sexual dimorphism of skulls, teeth, and long bones in mammoths, Mammuthus primigenius (Blumenbach 1799) // Shoshani J. \& Tassy P. (eds.), Proboscidea. Oxford, New York, Tokyo: Oxford University Press. P.260-267.

Baygusheva V.S. 1980. [Mammoth Mammuthus primigenius Blum. from the left bank of Severskiy Donets River] // Trudy Zoologicheskogo instituta AN SSSR. No.93. P.75-80 [in Russian].

Baygusheva V.S. \& Titov V.V. 2008. Palaeoloxodon elephant from the Sea of Azov Region (Russia) // Abstr. $6^{\text {th }}$ meeting of the European Association of Vertebrate Palaeontologists. Spišská Nová Ves: Museum of Spiš. P.1214.

Baygusheva V.S., Titov V.V. \& Timonina G.I. 2012. Two skeletons of Mammuthus trogontherii from the Sea of Azov Region // Quaternary International. Vol.276-277. P.242-252.

Christiansen P. 2004. Body size in proboscideans, with notes on elephant metabolism // Zoological journal of the Linnean Society. Vol.140. P.523-549.

Dubrovo I.A. 1960. [Ancient elephants of the SSSR] // Trudy Paleontologicheskogo instituta AN SSSR. No.85. 78 p. [in Russian]

Dubrovo I.A. 1975. Mammuthus trogontherii trogontherii (Pohlig) aus dem Pleistozän von Tiraspol // Quartärpaläontologie. Bd.1. S.125-155.

Dubrovo I.A., Rengarten N.V. \& Zelikson E.M. 1979. [Mammuthus trogontherii chosaricus Dubrovo from the Middle Pleistocene of Ciscaucasia and conditions of habita- tion] // Byulleten' komissii po izucheniyu chetvertichnogo perioda. No.49. P.63-77 [in Russian].

Dubrovo I.A. 1966. [Systematical position of the elephant of Khozar faunistic complex] // Byulleten' komissii po izucheniyu chetvertichnogo perioda. No.32. P.63-74 [in Russian].

Driesch von den A.A. 1976. Guide to the measurement of animal bones from archaeological sites // Peabody Museum of Archaeology and Ethnology. Bulletin No.1. Cambridge: Harvard University. $137 \mathrm{p}$.

Foronova I.V. 2001. [Quaternary mammals of the SouthEast of Western Siberia (Kuznetsk Basin): phylogeny, biostratigraphy, and palaeoecology]. Novosibirsk: Publishing House of Siberian Branch, Russian Academy of Sciences. 243 p. [in Russian]

Foronova I.V. 2014. Mammuthus intermedius (Proboscidea, Elephantidae) from the late Middle Pleistocene of the southern Western and Central Siberia, Russia: the problem of intermediate elements in the mammoth lineage // Russian Journal of Theriology. Vol.13. No.2. P.71-82.

Garutt V.E. 1972. [The skeleton of the Khazarian mammoth, Mammuthus cf. chosaricus Dubrovo from the Middle Pleistocene deposits of the Or'ya River (Kama River Basin) // Yakhimovich V.L. (ed.). Voprosy stratigrafii i korrelyatsii pliotsenovykh i pleystotsenovykh otlozheniy severnoy i yuzhnoy chastey Predural'ya. Ufa: AN SSSR. Vol.2. P.35-56 [in Russian].

Garutt V.E. \& Foronova I.V. 1976. [Research on the Teeth of Extant Elephants: Methodological Recommendations]. Novosibirsk: Institute of Geology and Geophysics. 36 p. [in Russian]

Garutt V.E. 1954. [Southern elephant Archidiskodon meridionalis (Nesti) from Pliocene of northern coast of the Sea of Azov] // Trudy komissii po izucheniyu chetvertichnogo perioda. Vol.10. No.2. 76 p. [in Russian]

Garutt V.E. 1977. [Dental system of elephants during ontogenesis and phylogenesis] // Trudy Zoologicheskogo Instituta AN SSSR. No.73. P.3-36 [in Russian].

Garutt V.E. 1992. [The skeleton of mammoth Mammuthus primigenius (Blumenbach, 1799) from the neighbourhood of Kozlovo village of Chermezsk area Perm' Region] // Muraviev I.S. \& Solodukho M.G. (eds.). Volga Fauna of Pleistocene Mammals in Geological and Mineralogical Museum of the Kazan State University. Kazan: Kazan State University. P.31-54 [in Russian].

Golovachev M.V. 2011. [About the find of Khazarian mammoth skeleton in Chernyi Yar district of Astrakhan Region in July 1996] // Biological museums: the role and place in scientific-educational space. Makhachkala: Dagestan State University. P.9-11 [in Russian].

Golovachev M.V. \& Titov V.V. 2015. [To the question about the sexual membership of skeleton of Mammutus cf. chosaricus remains from Singil deposits from the Astrakhan district (near Chernyi Yar village, 1996) // Kurapov A.A., Gerasimidi E.I., Tarkova R.A. (eds.). Astrakhanskie kraevedcheskie chteniya. Astrakhan: Sorokin R.V. Publishes. Vol.7. P.15-18 [in Russian].

Gromov V.I. 1935. [Stratigraphical significance of the Quaternary mammals of the Volga area] // Byulleten' komissii po izucheniyu chetvertichnogo perioda. Vol.4. No.2. P.309-324 [in Russian]. 
Gromov V.I. 1948. [Palaeontological and archaeological substantiation of stratigraphy of Quaternary terrestrial sediments in the USSR territory (Mammals, Palaeolithic)] // Trudy Geologicheskogo Instituta, Geological Series. Moscow: Academy of sciences of the USSR. Vol.64. No.17. 520 p. [in Russian]

Gromov V.I., Alekseev M.N., Vangengeim E.A., Kind N.V., Nikiforova K.V. \& Ravskii E.I. 1965. [Correlation scheme for Anthropogene deposits of Northern Eurasia] // Nikiforova K.V. (ed.). Correlation of Anthropogene deposits of Northern Eurasia. VII Congress of INQUA Abstracts. Moscow: Nauka. P.5-33 [in Russian].

Gromow W.I. \& Garutt V.E. 1975. Mandibel-Reste einer Fruhform des Mammuthus primigenius (Blumenbach) von Weimar-Ehringsdorf // Quartärpaläontologie. Bd.1. S.453-464.

Jachmann H. 1988. Estimating age in African elephants: a revision of Laws' molar evaluation technique // African Journal of Ecology. Vol.26. P.51-56.

Jourdan C. 1861. Des terrains sidérolitiques // Comptes Rendus des Academie des Sciences, Paris. Vol.53. P.1009-1014.

Kahlke R.D. 1990. Zur festlegung des lectotypus von Mammuthus trogontherii (Pohlig, 1885) (Mammalia, Proboscidea) // Quartärpaläontologie. Bd.8. S.119-124.

Kirillova I.V., Shidlovskiy F.K. \& Titov V.V. 2012. Kastykhtakh mammoth from Taimyr (Russia) // Quaternary International. Vol.276-277. P.269-277.

Kotsakis T., Palombo M.R. \& Petronio C. 1978. Маттиthus chosaricus e Cervus elaphus del Pleistocene Superior di via Flaminia (Roma) // Geologica Romana. Vol.17. P.411-445.

Labe B. \& Guérin C. 2005. Réhabilitation de Mammuthus intermedius (Jourdan, 1861), un mammouth (Mammalia, Elephantidae) du Pléistocène moyen récent d'Europe // Comptes Rendus Palevol. Vol.4. P.235-242.

Larramendi A. 2016. Shoulder height, body mass and shape of proboscideans // Acta Palaeontologica Polonica. Vol.61. No.3. P.537-574.

Laws R.M. 1966. Age criteria for the African elephant // East African Wildlife Journal. Vol.4. P.1-37.

Lee P.C., Sayialel S., Lindsay W.K. \& Moss C.J. 2012. African elephant age determination from teeth: validation from known individuals // African Journal of Ecology. Vol.50. P.9-20.

Leont'ev O.K. \& Foteeva N.N. 1965. [The origin and age of the Baer hillocks] // Izvestiya AN SSSR. Seria Geographicheskaya. No.2. P.212-215 [in Russian].

Lister A.M. 1996. Sexual dimorphism in the mammoth pelvis: an aid to gender determination. // Shoshani J. \& Tassy P. (eds.). The Proboscidea. Evolution and palaeontology of elephants and their relatives. Oxford, New York, Tokyo: Oxford University Press. P.204-213.

Lister A.M. 1999. Epiphyseal fusion and postcranial age determination in the wooly mammoth Mammuthus primigenius // Deinsea. Vol.6. P.79-87.

Lister A.M., Sher A.V., Van Essen H. \& Wei G. 2005. The pattern and process of mammoth evolution in Eurasia // Quaternary International. Vol.126-128. P.49-64.

Lister A.M. \& Stuart A.J. 2010. The West Runton mammoth (Mammuthus trogontherii) and its evolutionary significance // Quaternary International. Vol.228. P.180-209.

Maglio V.J. 1973. Origin and evolution of the Elephantidae // Transactions of the American Philosophical Society. Vol.63. 149 p.
Mashchenko E.N. 2004. Teeth morphology in woolly mammoth (Mammuthus primigenius) during Late Pleistocene of Eastern Eurasia // Lazarev P. (ed.). The Yukagir Mammoth: Outcome of the First Stage of Research Work. Abstracts of International Conference, Yakutsk: Yakut Scientific Centre of the Siberian Branch of the Russian Academy of Sciences. P.48.

Mol D., Bergh van den G.D. \& Vos de J. 1999. Fossil proboscideans from the Netherlands, the North Sea and the Oosterschelde estuary // Deinsea. Vol.6. P.119-145.

Obada T. 2014. Evidence of contact between Mammuthus intermedius (Jourdan, 1861) and ancient humans from Duruitoarea Veche, Republic of Moldova: preliminary data // Abstract Book of the $\mathrm{VI}^{\text {th }}$ International Conference on Mammoths and their Relatives. Thessaloniki: Scientific Annals, School of Geology, Aristotle University. Special Vol.102. P.145-146.

Obada T. \& David A. 2008. Mammuthus cf. chosaricus (Dubrovo, 1966) (Mammalia, Proboscidea) de la Duruitoarea Veche, Republica Moldova. Structura şi funcționarea ecosistemelor în zona de interferență biogeografică (simpozion internațional consacrat jubileului de 60 de ani al academicianului Ion Toderaş), Chişinău: Ştiința. P.209-211.

Osborn H.F. 1942. Proboscidea. A monograph of the discovery, evolution, migration and extinction of the mastodonts and elephants of the World: Vol. II. Stegodontoidea Elaphantoidea. New York: American Museum Press. 828 p.

Palombo M.R. \& Ferretti M.P. 2005. Elephant fossil record from Italy: knowledge, problems, and perspectives // Quaternary International. Vol.126-128. P.107-136.

Stansfield F.J. 2015. A novel objective method of estimating the age of mandibles from African elephants (Loxodonta africana africana) // PLoS ONE. Vol.10. No.5. e0124980. doi:10.1371/journal.pone.0124980

Titov V. \& Golovachev M. 2014. Data on elephants from Middle - Upper Pleistocene sediments of Astrakhan Volga area (Astrakhan Region, Russia) // Abstract Book of the $\mathrm{VI}^{\text {th }}$ International Conference on Mammoths and their Relatives. Thessaloniki: Scientific Annals, School of Geology, Aristotle University. Special Vol.102. P.200.

Zakrevska G. 1935. [Elephas trogontherii Pohlig from the right bank of Middle Dnieper] // Trudy Instituta Geologicheskikh Nauk. Kiev: Akademiya Nauk Ukrainskoi SSR. Vol.5. P.1-138 [in Ukrainian].

Zastrozhnov A., Danukalova G., Golovachev M., Titov V., Tesakov A., Simakova A., Osipova E., \& Yakovlev A. 2015. Singil deposits in the Quaternary sequence of the Lower Volga area: new data and new constrains (Russia) // Proceedings IGCP 610 Plenary Conference and Field trip "From the Caspian to Mediterranean: Environmental Change and Human Response during the Quaternary". Moscow: MSU Press. P.201-204.

Zastrozhnov A., Danukalova G., Golovachev M., Titov V., Tesakov A., Simakova A. \& Osipova E. 2017. Singil deposits in the Quaternary scheme of Lower Volga Region: new data // Stratigraphy. Geological correlation (in press).

Ziegler R. 2001. An extraordinary small mammoth (Mammuthus primigenius) from SW Germany // Stuttgarter Beiträge zur Naturkunde. Serie B. No.300. 41 p. 